\title{
ORION-Art Collections and Collectors in Portugal
}

\author{
Vera Mariz ${ }^{1}$, Rosário Salema de Carvalho ${ }^{1, *} *$, Fernando Cabral ${ }^{2}$, Maria João Neto ${ }^{1}$, \\ Clara Moura Soares ${ }^{1}$ and Natália Jorge ${ }^{2}$ \\ 1 ARTIS-Instituto de História da Arte, Faculdade de Letras, Universidade de Lisboa, 1649-004 Lisbon, \\ Portugal; vera.mariz@letras.ulisboa.pt (V.M.); mjneto@letras.ulisboa.pt (M.J.N.); \\ claramourasoares@letras.ulisboa.pt (C.M.S.) \\ 2 Sistemas do Futuro-Multimédia, Gestão e Arte, Lda., 4050-276 Oporto, Portugal; \\ fcabral@sistemasfuturo.pt (F.C.); natalia@sistemasfuturo.pt (N.J.) \\ * Correspondence: rscarvalho@letras.ulisboa.pt; Tel.: +351-933-300-322
}

Received: 27 January 2019; Accepted: 28 March 2019; Published: 2 April 2019

\begin{abstract}
ORION is a digital art history research-oriented project focused on the study of art collections and collectors in Portugal, supported on a relational database management system. Besides the obvious advantage of organizing and systematizing an enormous amount of information, promoting its analysis, this database was specifically designed to highlight the relationships between data. Its relational capacity is not only one of the most relevant features of ORION, but a differentiating quality, one step forward in comparison to other international databases and studies that use digital methodologies. This article discusses the methods and the advantages of using ORION in research related to the history of collecting, art markets and provenance of art objects in Portugal, where it is the very first time that an approach such as this is intended, looking for a systematization of data that paves the way to the emergence of new research questions. Furthermore, and because ORION aims to share the data and knowledge with other projects, institutions and researchers, the database uses different international standards, such as data structure (CIDOC-OIC and Getty-CDWA), controlled vocabulary (Iconclass, Art and Architecture Thesaurus (AAT), Thesaurus of Geographic Names (TGN), and Union List of Artist Names (ULAN)) and communication and exchange of information (CIDOC-CRM).
\end{abstract}

Keywords: study of collections; database management systems; documentation standards; controlled vocabularies; online collections

\section{Introduction}

ORION-Art Collections and Collectors in Portugal is a digital art history research-oriented project promoting the research and study on art collections and market agents, whether Portuguese or foreign, living in Portugal. Supported on a relational database management system, ORION project aims to gather and process a large amount of different data favoring a systematization that allows to develop analyses and interpretations referring to Portuguese art collectors and collections, as well as new perspectives on the dynamics of artistic markets (transaction mechanisms, forms of intervention and interaction between the different agents). Furthermore, in due course, it may trigger new questions, which are likely to deepen our knowledge in the field of art collecting.

ORION's main objectives can be compared with a permanent expanding net, with the individual objects and their specificities in the center, that can be extended almost indefinitely by integrating and relating to other related objects, collections, collectors, auction houses, and so on, promoting approaches of close and distant readings. Concretizing, and in a general overview, ORION aims to study the objects' history from their conception to the present day-retracing the owners (provenance) - as well as to document the different artistic tastes and trends during a specific timespan. More specifically, it is important to document the objects' provenance or ownership through the analysis of inventories, 
testaments, auction catalogues and other sources; to determine the circumstances that led to their acquisition; and to identify market agents (experts, dealers and auction houses).

ORION is developed by ARTIS (Art History Institute), a research unit based in the School of Arts and Humanities, University of Lisbon, and coordinated by the authors of the present paper, a team of art historians and technologists using the role-based model for collaboration proposed by Tracey Berg-Fulton, Alison Langmead, Thomas Lombardi, David Newbury, and Christopher Nygren [1]. Organized according to a "project structure", it is a work in progress, gathering the contributions of the ARTIS researchers as well as of students, interns and fellows. In fact, it is a powerful tool to be used by researchers and students for organizing and improving their work, as well as sharing its results in open access.

\section{Materials and Methods}

In an initial overview, ORION could be defined as a provenance project, considering this concept as the "history of the owners or others in possession of a work of art or architecture, or group of works" [2]. Moreover, a broader definition of provenance, including the history of taste and collecting, both individual and collective [3,4], contributes to classify ORION as a provenance project. However, despite the team being aware of the legal and ethics issues, the aim is not restitution but mainly the creation and construction of knowledge about works of art, both individually and assembled in collections amassed by someone-a collector-through very different ways; these include commissions directly made to the artists, sales, inheritances, auctions, payments for debts, and so on. Summing up and bearing in mind ORION's designation, its aim is the study of art collectors and collections in Portugal. Although provenance research is in fact promoted, the project is art history oriented, and this feature shifts the way it faces other provenance projects [5].

Despite being the very first time that a systematized approach such as this is intended, the idea of studying the collections of Portuguese art in an extensive way is not new and the publications of the ORION promoters over several years show evolution in the field [6-12]. In Portuguese history, the 1755 earthquake is traditionally highlighted because of its dramatic impact on heritage, mainly due to the destruction it provoked. However, after that natural catastrophe, two key political moments caused much more damage to the national historic and artistic heritage, and ultimately shaped the history of collecting: the extinction of religious regular orders in 1834 as well as the suppression of their assets; and the implantation of the republic in 1910 that led to the subsequent nationalization of the royal heritage and the publication of a law by which the state was separated from the churches (1911), thus affecting secular clergy. These troubled periods originated the dispersal of cultural heritage through auctions or simply by loot, as well as the acquisition of works of art by foreign collectors [13-15]. Consequently, the identification of the origins of works of art in museums and private collections became an area of study that has been explored by few art historians. Moreover, we must bear in mind that the royal, noble and clergy collections of the 15th-19th centuries included several masterpieces; some were destroyed or disappeared in 1755 and others simply dispersed due to different factors, including the political ones described above. On the other hand, researching Portuguese art demands the recognition of its specificity in line with the expansion of the field to an international context, given that Portuguese art belongs to a visual and cultural matrix that endures beyond European borders. Objects such as Indo-Portuguese furniture or ivory became valued pieces in the global art market, thus deserving a specific approach in connection with other international projects.

Thus, the motivation behind a collection and collectors project in Portugal differs from what is observed in the international scene, mostly focused on provenance and largely shaped, for example, by the consequences of the Second World War [16]. ORION intends to study the works of art, as well as the collections and collectors, but also the provenience of those pieces, retracing the objects' itineraries from the very beginning - the moment of creation— to the present day. Furthermore, it will consider the places where the objects were located (dealing with the concept of "integrated heritage", meaning 
the theoretically undivided unity formed by a given building and its composing assets), gathering data about the object itself and documenting everything related to it.

Considering the growth of digital art history projects in recent years, ORION was conceived to take full advantage of the technology now available to art historians, such as efficient work tools that can contribute to the advancement of existing knowledge. Therefore, the project started with a broader discussion firstly about the main research questions we wanted to ask, and secondly about the best methods to answer those questions, joining art historians and information technology (IT) experts in an interdisciplinary approach that is, for the team, the cornerstone of success in digital art history projects.

Bearing in mind the assumptions described and considering the research questions addressed for a long time by the art historians' team, the most important answers ORION wants to deal with are the following: Who were the Portuguese or foreign collectors established in Portugal mainly during the 19th and 20th centuries, as well as the ones in previous centuries? Who were the economic agents? What relationships between collectors and other market agents, such as dealers, antiquarians, auctioneers, etc., can we identify? Which was the prevailing taste in specific periods? What were the dominant acquisitions practices (auctions, donations, changes, etc.)? Which were the real dimensions of the Portuguese art market in a specific time span?

Those are large spectrum questions, so we need a huge amount of data to answer them. Thus, in what concerns the issue of scale, particularly suited to benefit from a digital environment [17], the need to find a way of gathering, organizing and analyzing vastly different data was clear to ORION's team. To solve this problem, a structured database seemed the best solution. The interdisciplinary team faced all these issues and analyzed similar projects, mainly provenance projects, to conclude that ORION needs not only a digitized approach to primary and secondary sources, such as the one provided by the Getty Provenance Index databases, but mainly a database with an "inventory" approach, e.g., one that privileges the objects and their documentation, linking everything with everything. Starting from the "object", at the heart of this relational database, we expect to link objects, auctions, collectors and other market agents, thus contributing to a renewed perspective of a universe characterized by multiple and intricate relationships. In fact, its relational capacity is the most important feature and novelty of the project.

Once it was decided that the "object" was the nucleus of the project around which other areas are organized (events, entities, and archive-library), we selected a database management system already in use in the market-InArte - developed by Sistemas do Futuro (Figure 1). On the one hand, InArt was designed for managing museum objects, thus meeting the previously defined requirements. On the other hand, it complies with international standards of management and documentation of cultural heritage, paying particular attention to the standards developed by the International Committee for Documentation of the International Council of Museums (ICOM-CIDOC), the Normalización documental de Museos (Spanish Ministry of Culture), and Spectrum: The UK Museum Collections Management Standard (Collections Trust) [18]. Moreover, it can be mapped with the International Guidelines for Museum Object Information: the CIDOC Information Categories and the Categories for the Description of Works of Art (CDWA) as well as with the Cataloging Cultural Objects: A Guide to Describing Cultural Works and Their Images $(\mathrm{CCO})$ as a standard to classify and describe works of art.

Then, and after the crucial decisions about what information groups and categories should be used, we faced the issues related with controlled vocabulary [19-22]. Considering the advantages of using international thesauri that facilitate communication and crossing data through databases, it was decided to use the Getty vocabularies: Art $\mathcal{E}$ Architecture Thesaurus (AAT); Union List of Artist Names (ULAN); and Thesaurus of Geographic Names (TGN). Unfortunately, for now, and due to technical issues, those vocabularies are not in ORION through LOD tools but through lists using the Getty IDs. To catalogue the iconography the choice was Iconclass, already in use in other digital projects from ARTIS-the Az Infinitum [23] — to which ORION is intended to crossover. In the near future, we aim to interconnect ORION with other projects, particularly the Project for the Study of Collecting 
and Provenance (PSCP), from the Getty Research Institute, where there are already data from other European countries, although Portugal remains absent due to lack of research. This way, not only will the ORION project acquire more visibility, but it will also benefit from integration within a vast database, which will reveal new historical links and interpretations.
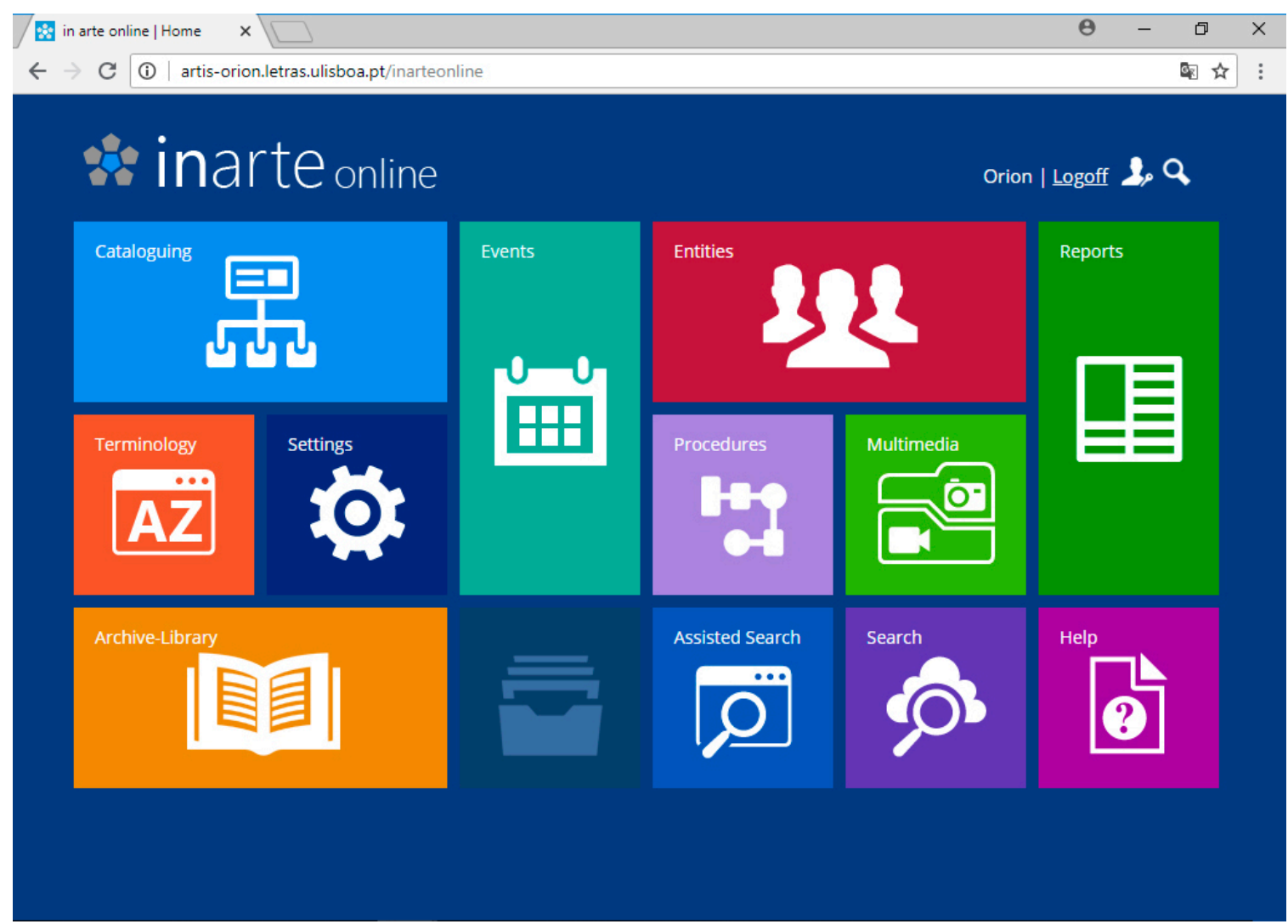

Figure 1. Schema of InArte Online modules.

ORION's team is aware of the huge effort regarding infrastructure, research and funding that is necessary to accomplish the project's aims. However, this is a long-term project and not an individual one, with a short lifespan. Thus, the strategy was to focus on specific collections or collectors, e.g., subdividing the main issue in small parts, which are easier to deal with. Once the main infrastructure is ready - the database- the most relevant task is to gather data from specific collectors or collections as is the case of Sir Francis Cook, recording all objects of its collection even those we do not know, but are registered in auctions' files, for example. The idea is that, by publishing and sharing the data in a structured and standardized way, it will be linked to other data in the future or could be enriched through the contribution of other scholars or even by the general public (through the crowdsourcing collaboration we want to implement).

In March 2018, the InArt database was finally prepared to be used. The recent studies carried out on Francis Cook (1817-1901) [12] and the international dimension of his collection, on the 200th anniversary of his birth, as well as the fact that the collection includes pieces from different periods, types and provenances, made him an important case study to test the methodologies of the project. Thus, it is an object of the Francis Cook collection that we take as case study to explain the potential of ORION. 


\section{Results}

\section{Francis Cook Collection as a Case Study}

Francis Cook (1817-1901), a highly successful English textile industrialist, became one of the most prominent art collectors of the 19th century $[6,12,24]$. In fact, his immense wealth, love for art and key relationships with influential art world figures, such as John Charles Robinson $(1824-1913)[6,25,26]$, allowed him to amass, not only but mainly, an extraordinary Old Masters gallery at his Richmond estate, Doughty House. However, his properties and art collection were by no means confined to England. In Portugal, specifically in Sintra, the determined businessman purchased, from 1856 onwards, several estates, such as the iconic Palace of Monserrate, formerly inhabited by his celebrated countryman, William Beckford (1760-1844), and eloquently immortalized by Lord Byron (1788-1824) in Childe Harold's Pilgrimage [9]. After the renovation of this 18th century building, a work commissioned from the architect James Thomas Knowles (1806-1884), and a no less impressive rehabilitation of the surrounding gardens, Francis Cook devoted himself to the acquisition of several antiquities able to match or, more likely, to increase the already high cultural significance of the place [9]. Living in England within a context increasingly marked by public exhibitions and the multiplication of private collections, Cook's interest in antiquities soon evolved to collecting fine art and decorative art. Soon after, with the guidance of the abovementioned connoisseur, John Charles Robinson, Francis Cook would become a noteworthy art collector whose collection was, in fact, partially displayed at the Palace of Monserrate. There, modern English and Indo-Portuguese furniture, Persian carpets, Chinese porcelains, Renaissance, Baroque and Neoclassical sculptures, reproductions of classical statues, Indian jalis, ancient Portuguese silver and 16th century Italian paintings filled every room, corridor and staircase, thus creating a multisensory, exuberant and exotic ambiance [9]. The not so happy ending of this One Thousand and One Nights revival, came in 1946, long after the death of Francis Cook and at a time when his descendants and heirs struggled with severe financial difficulties. That year, auctions of the estate and contents of the Palace of Monserrate were held by Casa Liquidadora Leiria \& Nascimento, Lda., an event during which the impressive art collection was irremediably scattered $[9,27]$.

During the exhibition held from December 2017 to May 2018 in the Palace of Monserrate to commemorate the 200th anniversary of the birth of Francis Cook, "Monserrate Revisited-The Cook Collection in Portugal", more than ninety objects were located, reunited, displayed and studied by different researchers. The results of these studies carried out, in the majority of the cases for the first time, were then compiled in a catalogue, which also contains several studies on the collector and his collection [12] (Figure 2). Within the ORION project, the totality of the objects catalogued on this occasion were registered in the previously mentioned database. Simultaneously, records of entities, such as the collector himself and other agents who played a fundamental role in those objects' history of ownership, and events, such as the auction held in 1946, were also created and interconnected in the database. With the aim of presenting the main characteristics and potential of the database, we have selected a few examples of such records.

As previously stated, the objects are the center of the project, around which the other database areas are organized. Therefore, we may start with the case of Vasco Fernandes' "Lamentation over the body of Christ/Saint Francis of Assisi/Saint Anthony" (Orion_00026) (Figure 3). This triptych is one of the most important works by the famous Portuguese painter known as Grão Vasco, as it is the first known signed work of the artist, and because its provenance links several collectors and other entities, both from the Portuguese and the international 19th and 20th century art markets. The record of this object, as of others, is composed of information groups and fields crucial for the general knowledge of the artwork (Figure 4). These are as follows: inventory number, object designation, authorship (author, type, and justification), classification, creation date (date, type, and justification), legal dispositions (type, reference, and date), style, iconographies, inscriptions (type, text, and position), materials, measurements (type, value, unit, and notes), numbers (number and type), origin (country 
and administrative division), provenance (type, entity, administrative division, date, justification, and notes), techniques, titles (type and title) and related records.

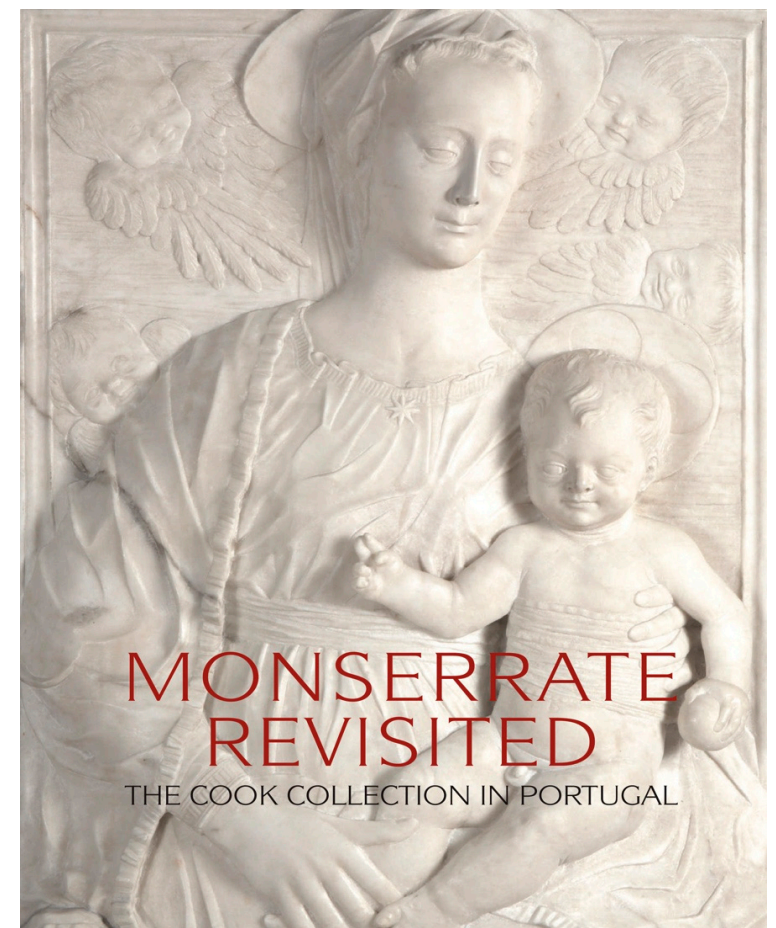

Figure 2. Cover of the catalogue Monserrate Revisited-The Cook Collection in Portugal, 2017.
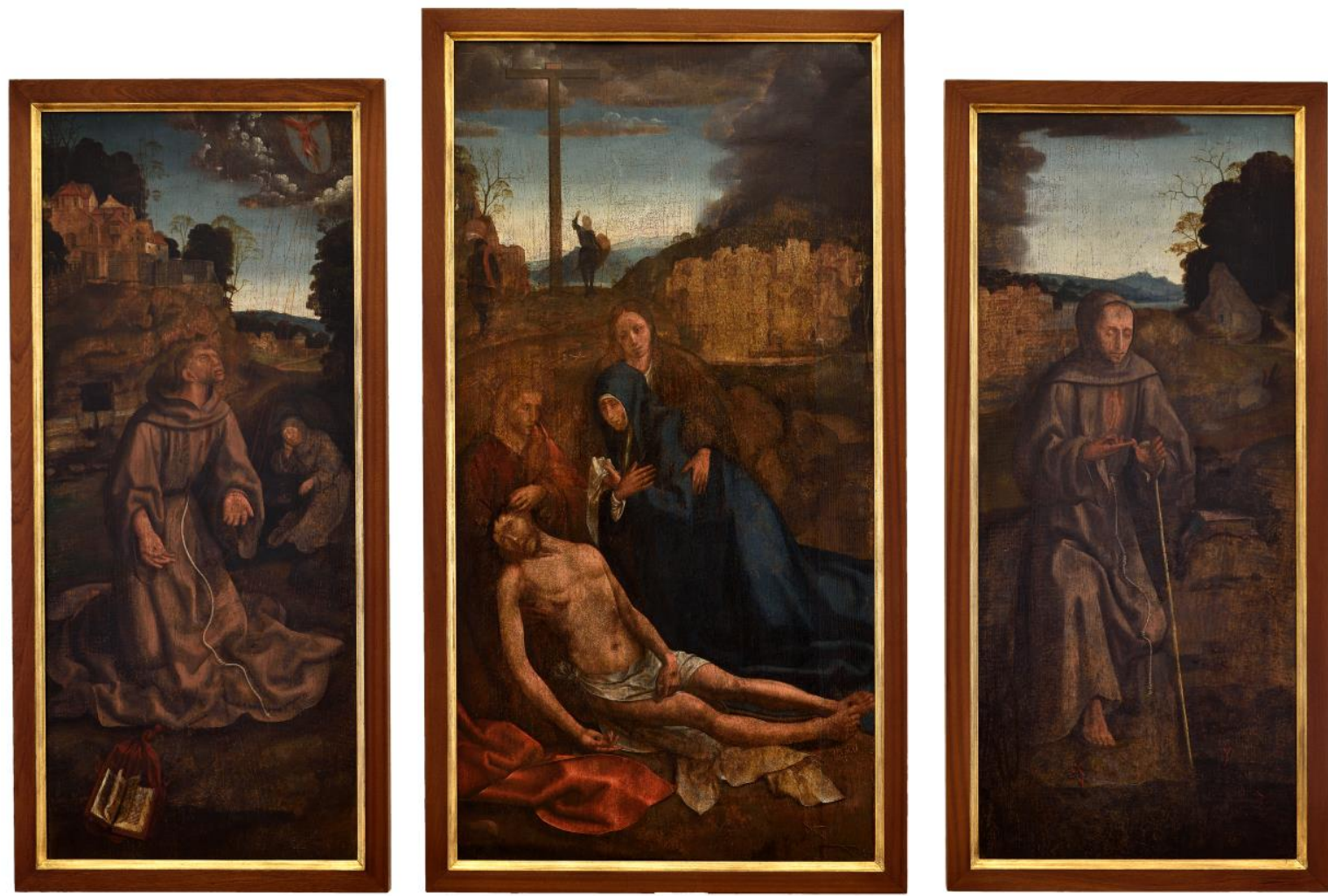

Figure 3. Lamentation over the body of Christ/Saint Francis of Assisi/Saint Anthony, known as triptych of Cook, Vasco Fernandes, ca. 1510-1530, Museu Nacional de Arte Antiga, Direção-Geral do Património Cultural, photograph: Alexandra Pessoa, 2016, Direção-Geral do Património Cultural/Arquivo de Documentação Fotográfica (DGPC/ADF). 
Cataloguing: Objects

Orion_00026

object designation

triptych
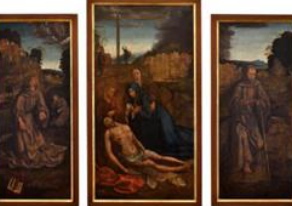

AUTHORSHIPS

\begin{tabular}{lll} 
Author & Authorship Type & Precision \\
\hline Fernandes, Vasco & painter -300025136 & attributed Isigned \\
CLASSIFICATIONS & \\
Classification & \\
\hline
\end{tabular}

paintings - 300033618

CHRONOLOGY

\begin{tabular}{llllll} 
Initial date & Precision - initial date & Final date & Precision - final date & Textual date & Justification \\
\hline & $\begin{array}{llll}\text { date assigned by } \\
\text { historiography }\end{array}$ & $00 / 00 / 1525$ & $\begin{array}{l}\text { date assigned by } \\
\text { historiography }\end{array}$ & circa 1520-1525 & Serrão 2017, 324
\end{tabular}

LEGAL DISPOSITIONS

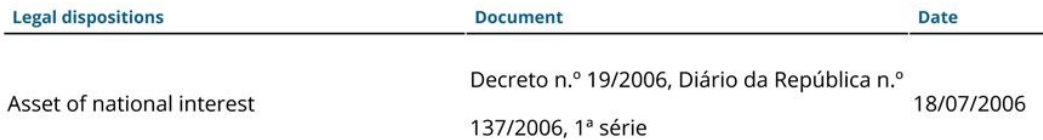

Style

Renaissance - 300021140

ICONOGRAPHIES

Iconography type

7 - Biblel73 - New Testament173D - Passion of Christ173D7 - from Christs deposition to his entombment (Matthew 27:58-66; Mark

15:46-47; Luke 23:53-56; John 19:39-42)

1 - Religion and Magic $\backslash 11$ - Christian religion $\backslash 11 \mathrm{H}$ - saints $\backslash 11 \mathrm{H}(\ldots)$ - male saints (with NAME)\11H(FRANCIS) - founder of the Order of Friars Minor (Franciscans), Francis(cus) of Assisi; possible attributes: book, crucifix, lily, skull, stigmatal11H(FRANCIS)5 -miraculous activities and events St. Francis of Assisil11H(FRANCIS)59 - stigmatization of St. Francis of Assisi: in retreat on Mount Alverna, he beholds a vision of Christ on the cross enveloped by wings (

Figure 4. Print preview of the ORION database showing part of the record Orion_00026.

The fact that, in the case of this particularly object, we are dealing with a known author, means that an author record must be created in the entities area, as filling in this field in an object record requires choosing a name from a list of standardized names. Therefore, this artwork signed by Vasco Fernandes as "VASCO FRZ" near the right foot of Christ, an inscription first disclosed by José de 
Oliveira Berardo in 1857 [28], is connected to the entity record of the artist in the corresponding area. However, the authorship information group is not the only one which links the different areas of the database, in this case the object with the entities. In fact, as we need to record the several owners, both proved and possible ones, of the triptych in the provenance group information, the same number of entities records were created in the respective area, namely the monastery of Saint Francis of Orgens (Viseu, Portugal), believed to be the place of origin [29] (p. 149); António José Pereira (1821-1895), the painter who accidently [30], as first reported by Oliveira Berardo [28] and then broadly disseminated by Maximiniano de Aragão [31], acquired the art work in 1857; Herbert Philip de Kantzow (1829-1915), a possible owner, whose ownership is suggested by a handwritten note of Herbert Frederick Cook (1868-1939) in his copy of "The Early Portuguese School of Painting" [32] (p. 18) [24] (p. 128); Francis Cook, who in 1875 stated that the painting was unexpectedly in his possession [6] (p. 423); and the Museu Nacional de Arte Antiga, as prior to his death, Herbert Cook expressed the wish to bequest the triptych to the Portuguese museum. Second World War (1939-1945) and other factors delayed the transfer of property of the painting considered by Kenneth Clark (1903-1983) during this process, as "a ghost of a painting, but an interesting and even beautiful painting" [33]. Nonetheless, in 1945, the celebrated triptych finally arrived in Lisbon [33-35]; and, lastly, the Museu Nacional Grão Vasco, where it is on loan from the Museu Nacional de Arte Antiga since 2010 (Figure 5).

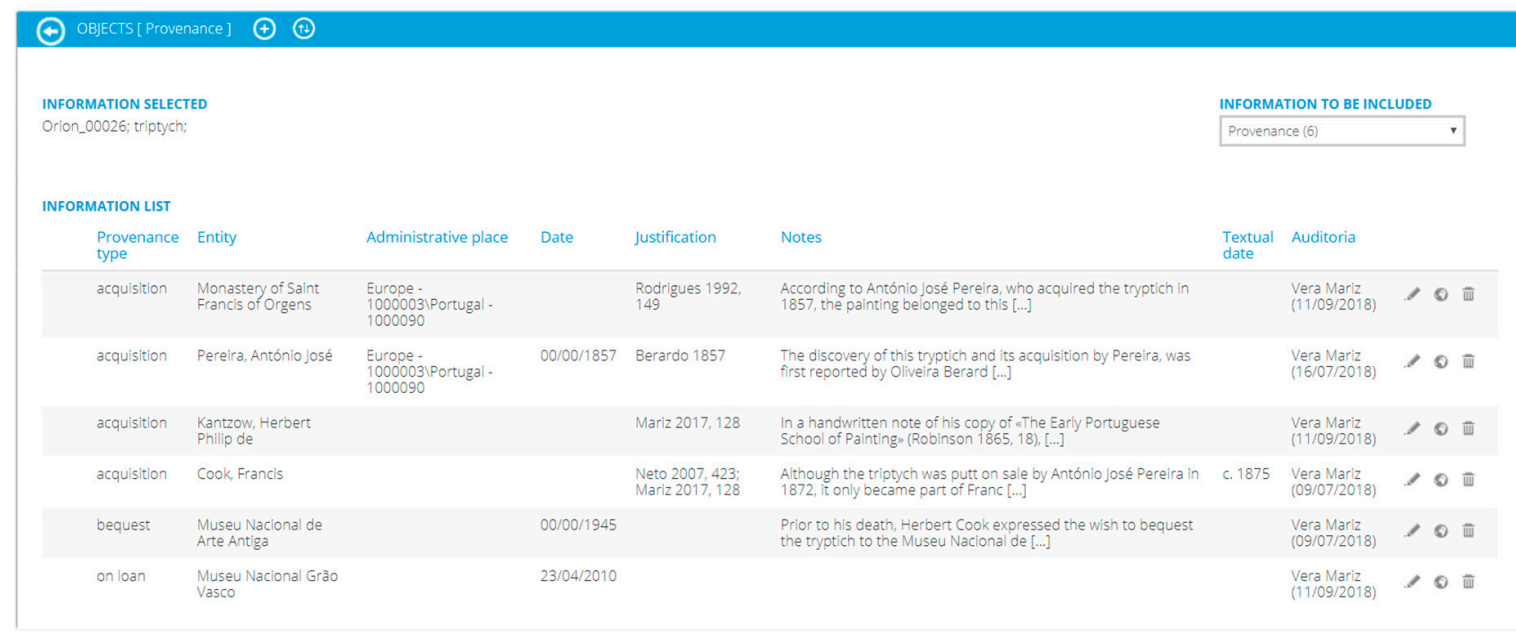

Figure 5. Print screen of the ORION database showing the provenance list.

These entities records are divided in different types: document authors (whose work was used as reference), authors (of artworks), collaborators (especially those responsible for conservation and restoration works), owners and actors (art market economic agents). Despite these differences, all of the abovementioned types of entities records present the same information groups and fields. For instance, Francis Cook is registered as owner and his record composition is as follows: type, full name, preferred name, biographical note, occupation, chronology (initial date, final date, textual date, event, and justification), other information, other names, and related records. These fields allow us to systematize in a normalized way, by using, for instance, the name listed in the Getty ULAN as the preferred term (Cook, Francis), the main aspects of the collector's life and career. The related records field is particularly relevant within the study of the collector and his collection, as all the objects registered in the database as owned, at some point, by Francis Cook are orderly displayed here. In the case of artists, such as Vasco Fernandes, all of the artworks registered in the database having him as author will also be linked to his entity record and virtually gathered in this field.

In addition to these two areas, objects and entities, the database also presents an area for recording information regarding events. These could be conservation procedures, exhibitions and other events, namely auctions. Therefore, the previously mentioned auction of the contents of the Palace of Monserrate held in 1946 is recorded in this area, with all the data systematized in the following 
information groups and fields: designation, type of event, synopsis, place (country and place), organization, initial date, final date, and related records (Figure 6). Once again, the inclusion of this last field allows us to rapidly have a precise knowledge of the objects which were auctioned at the event held in the Palace of Monserrate by Casa Liquidadora Leiria \& Nascimento, Lda., from 9 November to the "following days", between 14:00 and 19:00, and between 19:00 and 24:00, while the auction of the library took place on 12 December.
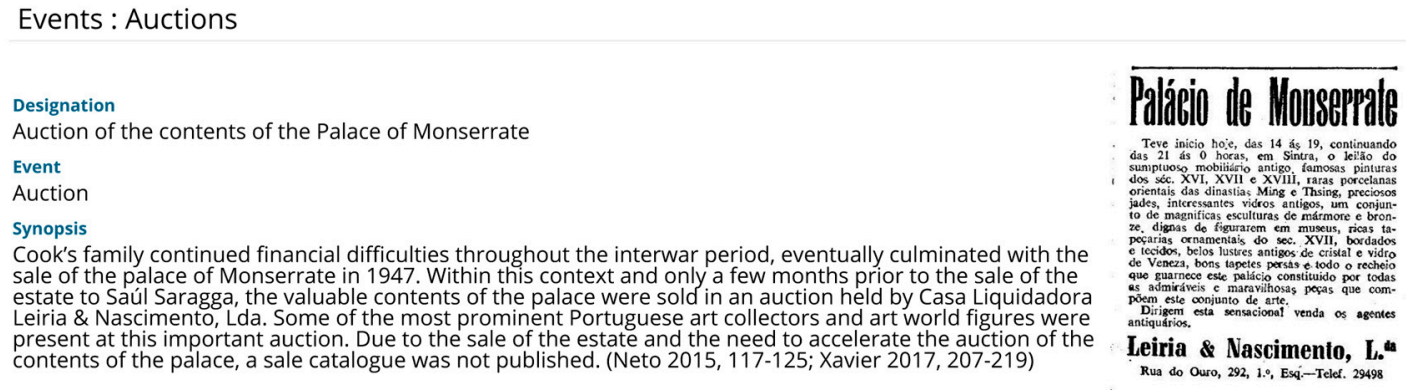

Figure 6. Print preview of the ORION database showing the auction record.

All of the data inserted in the previously described areas of the database result from conventional art history work methodologies, such as gathering and analyzing of information in libraries and archives, using both published and unpublished sources. The justification field present in different areas of the database is precisely used to substantiate the recorded information and to acknowledge the author of such argument, when needed. In some cases, in the absence of this field in particular, the reference, always cited according to The Chicago Manual of Style author-date system, is presented near to the respective textual information. In any case, all of the sources used during the elaboration of a record must originate their own records in the archive-library area, including manuscripts, monographs, electronic sources or periodicals. In the case of the recent catalogue published for the exhibition "Monserrate Revisited-The Cook Collection in Portugal", a now indispensable source for the study of the collector and his collection, the record is comprised of information regarding its identification number in the database (MON_00001), type of source, title, edition number, publisher city, year of publication, publisher, analytical monographs (when a monograph is composed of contributions by different authors), authorship and related records. Therefore, all records where this catalogue was used as reference are listed in this field (which works as a very detailed index).

\section{Discussion}

ORION is a project in progress and its transversality to a research unit-ARTIS-as well as it being understood as a powerful tool to be used by researchers and students, is a guarantee of its sustained growth in a near future. For now, and once the database is defined and working properly at the service of art history and its research questions, a step forward is needed to make all this information available to the scientific community and to the public in general though a website including a database interface [36]. Thus, following the same methodology of discussion used before, we joined art historians, web and graphic designers and IT experts to develop the general image of the project, starting by the logo and the color scheme (Figure 7), and now we are working on data visualizations. We are especially concerned with the ones able to provide the rise of new "patterns" and research questions, thus improving the knowledge in the field of collections and art collectors in Portugal in connection with international projects. 


\section{ORIPN
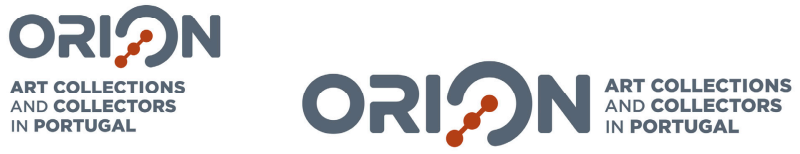

Figure 7. ORION logo, designed by Mafalda Matias.

The website will centralize all the information about the project. An institutional area will provide a brief overview on research questions and objectives, the team description (including short biographies along with the role and the timespan in which each participant was involved in the project), a list of publications with the possibility to download the papers available in open access, an area for news and a technical file with terms and conditions, citations and licensing.

However, the most important area will be an access point to search into the database, along with different data visualization tools. Although all database areas are interconnected, three access points will be provided: one focused on the objects, including visualization by collection, thus grouping the objects by different owners (for now, around 450 works of art, mainly paintings, drawings, sculptures, furniture and ceramics are recorded); another focused on the collectors; and a different one presenting the events, such as auctions, exhibitions and so on. All these access points will be made available in the usual forms-guided, simple and advanced.

Considering the database as an effective way of gathering and organizing the data, thus favoring its analysis, we left out an important feature-interpretation. The data are available and can be used by other researchers, but in the near future we also want to publish online (exploring the digital realm) the conclusions we will come across. We are not avoiding the peer-reviewed scholarly publication but thinking about leveraging the publications' results, e.g., by making them available in close association with the data themselves [37].

Finally, in what concerns visualizations, we are discussing alternative formulae for objects, collections and collectors, considering the concepts of storytelling as well as graphs intend to go one step further in providing, at least in the beginning, three different approaches.

With the aim of visualizing the entire story of each object, interconnected with all its information, we opted to deal with concepts of space and time as well as of storytelling. As we have shown through this paper, what is normal in a collection management system is that the whole system is focused on the catalogue of objects. Therefore, all the other modules are related to it in a direct way (such as authorship or provenance) or in an indirect way (such as the place of acquisition, the exhibitions in which it participated or all its bibliography) (Figure 8). The system used by ORION is based on the same concepts and guidelines, but intends to go a little further allowing cross-referencing the whole history of the object both in space and in time. To achieve this, we are using Google Maps API to map all the information about the object and to present it in a simple way, e.g., to tell the entire story of each object through a map organized chronologically as if it were a life story (Figure 9). In this context, it is worth noting the possibility to map the owners linked through the objects and thus highlighting the connections between "actors".

On the other hand, and considering the global scale of the project, aiming to deal with Portuguese and international collections and art collectors, the ORION project poses a great challenge particularly suited to benefit from the advantages made available by a digital environment [17]. In addition, the collaboration and interdisciplinarity required when working in the "digital realm" led us to consider the use of crowdsourcing resources applied to scientific research. Thus, one of the objectives of the ORION project is the use of the collaborative web allowing users of the website to contribute with information about the objects, artists, provenances and locations, through an area specifically designed for this purpose. 


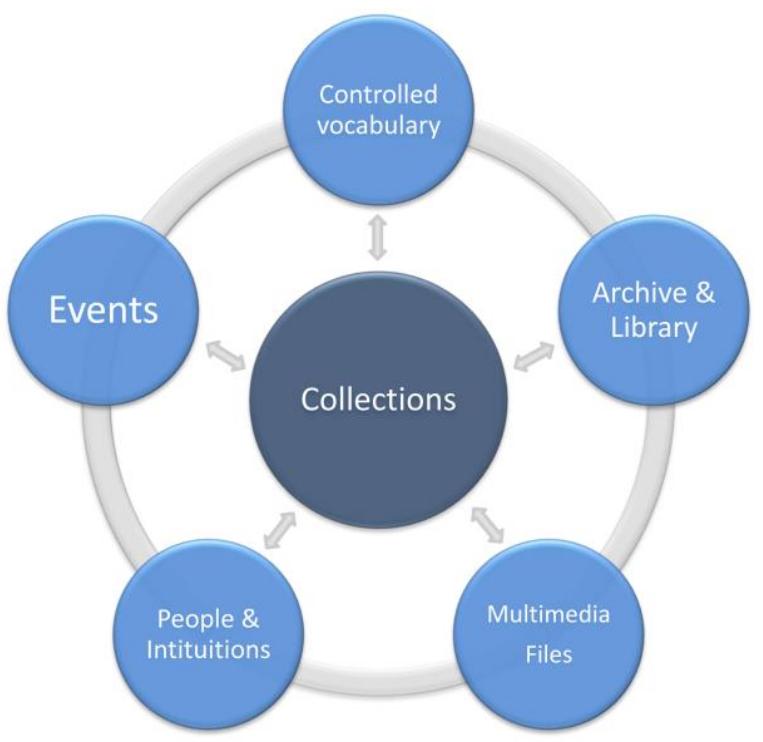

Figure 8. The relational data model.

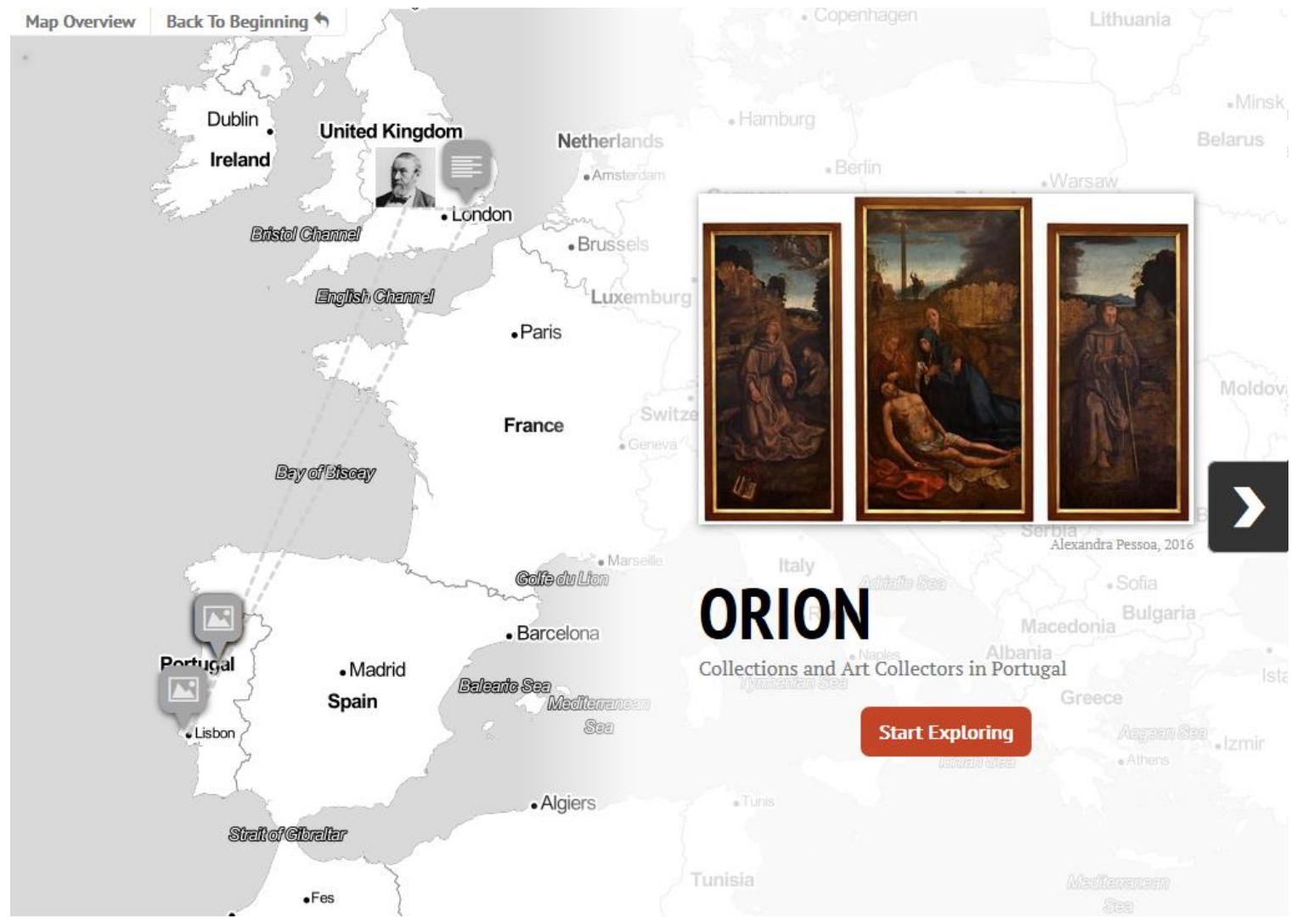

Figure 9. Story map-an object and its provenance.

In fact, the information regarding collectors and collection can be in private hands and this is one of the issues researchers have to deal with, sometimes without any success due to a variety of factors. The recent work carried out on the relationship between the collections of the Portuguese architect José Maria Nepomuceno (1836-1895) and João Maria Correia Ayres de Campos (1847-1920), 1st Count of Ameal, is a good example of how private information is inaccessible, but can be decisive in identifying works of art [38]. In this specific case, an ORION collaborator was close to descendants of the Count of Ameal and was able to access the pieces still in their possession, identifying some azulejo panels still with the auction numbers painted on the frames that belonged to Nepomuceno collection. They 
were sold in auction after his death, then acquired by the 1st Count of Ameal, again sold in auction after the Count's death, and finally acquired by the descendants of the Count, in whose hold they have remained until now. We hope that the existence of such a database can motivate private owners to come forward and collaborate by providing (or giving access to) information. Thus, attached to the object area, the website will provide a link to a page where users can insert their contributions. This information is stored in a database until an ORION project manager analyses its relevance and interest for the project, identifying the source or the contributor.

In recent years, some cultural institutions have begun exploring and developing public APIs for their museum collections. Knowing this new reality in the museums, we consider it is pertinent to introduce these kinds of tools in our project. Thus, the ORION project will also provide a REST-style application programming interface (API) for developers to be used in their products and services (Figure 10). The search/request to database is used to retrieve information and can be submitted remotely via HTTP. The objects are automatically generated to be used whenever you make an HTTP request (Figure 11). Responses are the data you get back from the API, providing a way to interact with the response data returned. Responses can return the desired data, and they can also be used to return errors. Our API is open to all and we are interested to see the innovative ways in which external users, researchers and organizations will use our data.

\section{in API Home Request About Contacts}

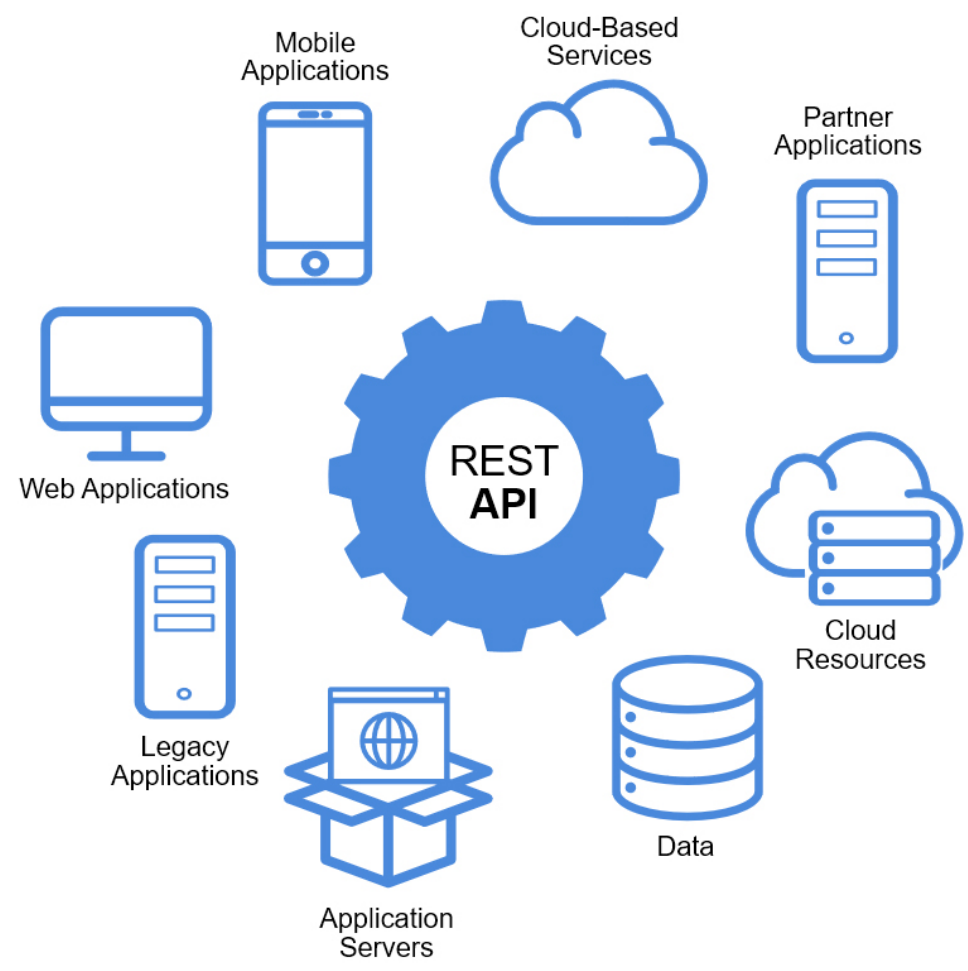

Figure 10. API public interface. 


\section{inAPI}

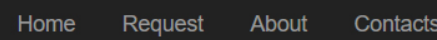

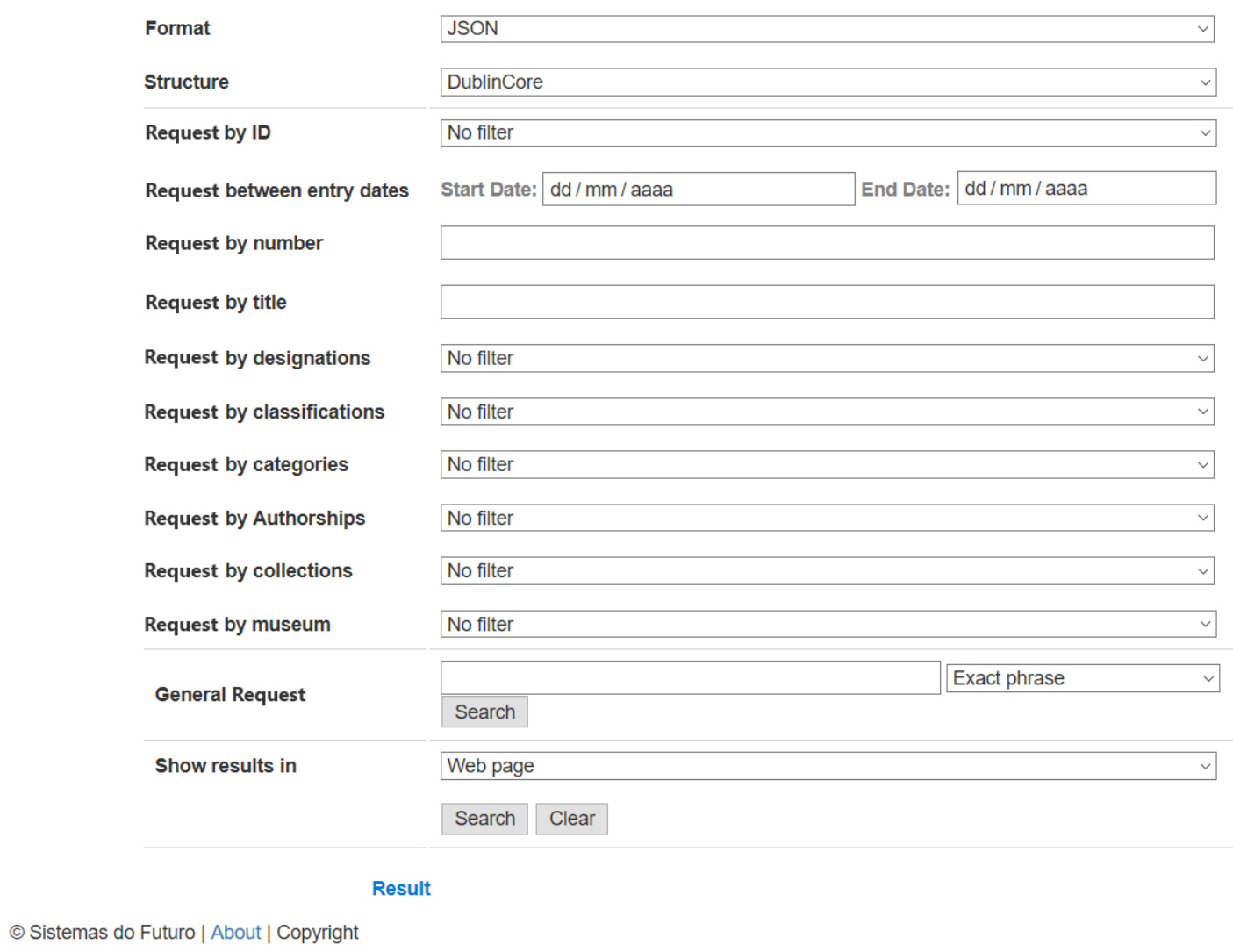

Figure 11. Using the API to get data from the Orion Project Database.

\section{Conclusions}

With the powerful interconnected management system InArt (using international controlled vocabularies), articulated with innovative visualization tools as well as with the crowdsourcing tool and API to provide data, we believe that the ORION project can be a really significant step towards gaining a renewed perspective on this particular field of study-the collections and art collectors-leveraging the Portuguese reality onto the international stage it deserves.

Author Contributions: Although all authors contributed substantially to the work reported, they are listed according to their involvement in the writing of this article. Conceptualization, M.J.N., C.M.S., V.M., R.S.d.C., F.C. and N.J.; methodology, V.M., R.S.d.C., F.C. and N.J.; software, F.C. and N.J.; validation, V.M. and R.S.d.C.; investigation, M.J.N., C.M.S., V.M.; data curation, V.M.; writing - original draft preparation, V.M., R.S.d.C. and F.C.; writing-review and editing, V.M., R.S.d.C., F.C., M.J.N. and C.M.S.; supervision, M.J.N. and C.M.S.; and project administration, M.J.N. and C.M.S.

Funding: This study was funded by national funds of FCT (Fundação para a Ciência e a Tecnologia), I.P. (FCT-Portugal) through the project UID/EAT/04189/2016; as well as by postdoctoral grants of the first and second authors (SFRH/BPD/116050/2016 and SFRH/BPD/84867/2012) both supported by the European Social Fund through the Human Capital Operational Programme (HCOP), and by national funds from the Ministry of Science, Technology and Higher Education.

Conflicts of Interest: The authors declare no conflict of interest.

\section{References}

1. Berg-Fulton, T.; Langmead, A.; Lombardi, T.; Newbury, D.; Nygren, C. A Role-Based Model for Successful Collaboration in Digital Art History. Int. J. Digit. Art Hist. 2018, 152-180. [CrossRef] 
2. Baca, M.; Harpring, P. (Eds.) Categories for the Description of Works of Art; J. Paul Getty Trust; College Art Association: New York, NY, USA, 2014. Available online: http:/ / www.getty.edu/research/publications / electronic_publications/cdwa/index.html (accessed on 22 December 2018).

3. Yeide, N.; Akinsha, K.; Walsh, A.L. The AAM Guide to Provenance Research; American Association of Museus: Washington, DC, USA, 2001.

4. Feigenbaum, G.; Reist, I. Provenance: An Alternate History of Art; Getty Research Institute: Los Angeles, CA, USA, 2012.

5. Fuhrmeister, C.; Hopp, M. Rethinking Provenance Research. Getty Res. J. 2019, 11, 213-231. [CrossRef]

6. Neto, M.J. Coleccionadores e Connaisseurs de obras de arte: Francis Cook (1817-1901) e John Charles Robinson (1824-1913) em Portugal. Artis, Revista do Instituto de História da Arte da Faculdade de Letras de Lisboa 2007, 1, 403-442.

7. Neto, M.J. (Ed.) ARTIS—Revista de História da Arte e Ciências do Património 2014, 2.

8. Neto, M.J.; Malta, M. (Eds.) Coleções de Arte em Portugal e Brasil nos séculos XIX e XX: Perfis e trânsitos; Caleidoscópio: Lisboa, Portugal, 2014.

9. Neto, M.J. Monserrate. A casa romântica de uma família inglesa; Caleidoscópio: Lisboa, Portugal, 2015.

10. Neto, M.J.; Malta, M. (Eds.) Coleções de Arte em Portugal e Brasil nos séculos XIX e XX. As Academias de Belas-Artes. Rio de Janeiro, Lisboa, Porto (1816-1836). Ensino, artistas, mecenas, colecções; Caleidoscópio: Lisboa, Portugal, 2016.

11. Soares, C.M. A Coleção de arte do Conde do Ameal: O leilão de 1921 e as aquisições do Estado Português para os Museus Nacionais. In Anais do II Colóquio Internacional Coleções de Arte em Portugal e no Brasil nos Séculos XIX e XX. Modos de ver e exibir em Brasil e Portugal; Neto, M.J., Malta, M., Cavalcanti, A., Oliveira, E.D., Couto, M.F.M., Eds.; Rio Books/EBA/UFRJ: Rio de Janeiro, Brazil, 2016; pp. 89-105, ISBN 978-85-94970-07-7.

12. Neto, M.J. (Ed.) Monserrate Revisitado. A Colecção Cook em Portugal; Caleidoscópio: Lisboa, Portugal, 2017.

13. Mariz, V. From Portugal to England. John Charles Robinson's purchases in the Portuguese art market. J. Hist. Collect. 2018, fhy057. [CrossRef]

14. Rodrigues, R. Entre a salvaguarda e a destruição: A extinção das ordens religiosas em Portugal e as suas consequências para o património artístico dos conventos (1834-1868). Ph.D. Thesis, Faculdade de Letras da Universidade de Lisboa, Lisboa, Portugal, 2017. Available online: http:/ /hdl.handle.net/10451/29993 (accessed on 6 March 2019).

15. Soares, C.M. A extinção das ordens religiosas em Portugal na implantação do Liberalismo: Efeitos sobre o património artístico dos conventos. In De Viollet-leDuc a la Carta de Venecia. Teoría y Práctica de la Restauración en el espacio Iberoamericano; LNEC: Lisboa, Portugal, 2014; pp. 9-16.

16. Other provenance projects are the Kress Provenance Research Project, developed by the Samuel H. Kress Foundation, the Frits Lugt, Collectors' Marks on Prints and Drawings (Fondation Custodia), relevant to the field, as well as the projects directly related with the WW2 as the Art Provenance World War II Research, developed by the Smithsonian Museums.

17. Jaskot, P.B. Debates in the Digital Humanities, edited by Matthew K. Gold. Vis. Resour. 2013, 29, $135-140$. [CrossRef]

18. Matos, A. SPECTRUM: Uma norma de gestão de coleções para os museus portugueses. Ph.D. Thesis, Faculdade de Letras da Universidade do Porto, Porto, Portugal, 2012. Available online: http:/ / repositorioaberto.up.pt/handle/10216/67304 (accessed on 22 December 2018).

19. Baca, M.; Harpring, P.; Lanzi, E.; McRae, L.; Whiteside, A. Cataloging Cultural Objects: A Guide to Describing Cultural Works and Their Images; American Library Association: Chicago, IL, USA, 2006.

20. Cobb, J. The Journey to Linked Open Data: The Getty Vocabularies. J. Libr. Metadata 2015, 15, $142-156$. [CrossRef]

21. Harpring, P. Introduction to Controlled Vocabularies Terminology for Art, Architecture, and Other Cultural Works; Getty Research Institute: Los Angeles, CA, USA, 2013.

22. Jorge, N. Ensaio sobre o AAT-Art \& Architecture Thesaurus: Proposta terminológica de adaptação à realidade portuguesa. Master's Thesis, Faculdade de Letras da Universidade do Porto, Porto, Portugal, 2011. Available online: http:/ / repositorio-aberto.up.pt/handle/10216/57042 (accessed on 22 December 2018). 
23. Az Infinitum-Azulejo Indexation and Referencing System. Is a Research-Oriented Project Also Based on a Relational Database Aiming to Document the Portuguese Azulejos (Tiles) Still Found In Situ. Az Infinitum Is Divided into Five Main Areas, Which Are Interconnected and Provide a Comprehensive Understanding of Each Tile Decoration. Available online: http:/ / redeazulejo.letras.ulisboa.pt/pesquisa-az (accessed on 1 January 2019).

24. Danziger, E. The Cook Collection, its founder and its inheritors. Burlingt. Mag. 2004, CXLVI, 444-458.

25. Davies, H. Sir John Charles Robinson (1824-1913): His Role as a Connoisseur and Creator of Public and Private Collections. Ph.D. Thesis, University of Oxford, Oxford, UK, 1992.

26. Mariz, V. John Charles Robinson. O amigo e conselheiro. In Monserrate Revisitado. A Colecção Cook em Portugal; Neto, M.J., Ed.; Caleidoscópio: Lisboa, Portugal, 2017; pp. 117-129, ISBN 9789896584818.

27. Xavier, H. Monserrate em leilão. In Monserrate Revisitado. A Colecção Cook em Portugal; Neto, M.J., Ed.; Caleidoscópio: Lisboa, Portugal, 2017; pp. 207-219, ISBN 9789896584818.

28. Berardo, J.O. O pintor Vasco Fernandes, de Vizeu. O Liberal 1857, 52.

29. Rodrigues, D. (Ed.) Grão Vasco e a pintura europeia do Renascimento; Comissão Nacional para as Comemorações dos Descobrimentos Portugueses: Lisboa, Portugal, 2002.

30. Santos, L.R. O Tríptico de Vasco Fernandes da Colecção Cook, de Richmond. Boletim do Museu Nacional de Arte Antiga 1947, 1, 83-103.

31. Aragão, M. Grão Vasco ou Vasco Fernandez. Pintor Viziense, principe dos pintores portugueses; S.n.: Viseu, Portugal, 1900.

32. Robinson, J.C. The Early Portuguese School of Painting; With Notes on the Pictures at Viseu and Coimbra, Traditionally Ascribed to Gran Vasco; S.n.: London, UK, 1865.

33. Clark, K. ca. Museu Nacional de Arte Antiga's archive: Registador n. 39, 1943, n. 3, January-December, 45 to 86, George West to João Couto, 19 October 1943.

34. O Tríptico de Vasco Fernandes oferecido a Portugal chegou ontem de Inglaterra. Diário de Notícias, 12 May $1945 ; 1$.

35. On this lengthy process see the record held by the Museu Nacional de Arte Antiga's archive: Registador $\mathrm{n}$. 39, 1943, n. 3, January-December, 45 to 86; Registador n. 45, 1945, n. 2, January-December, 16 to 40.

36. ORION-Art Collections and Collectors. Available online: http://artis-orion.letras.ulisboa.pt.

37. Card, B.; Droth, M.; Scutt, T.; Turner, S.V. Beyond the PDF: Expanding Art History Digitally with British Art Studies. Vis. Resour. 2019, 34. [CrossRef]

38. Mariz, V.; Carvalho, R.S.; Ricardo, F.; Campos, M.A. Nepomuceno e Ameal: A história de duas colecções de azulejo. ARTIS—Revista de História da Arte e Ciências do Património 2018, 6, accepted. 